\title{
Human- and Mouse-Inducible Nitric Oxide Synthase Promoters Require Activation of Phosphatidylcholine- Specific Phospholipase C and NF- $\mathrm{KB}$
}

\author{
Sergei V. Spitsin,* John L. Farber, ${ }^{\dagger}$ Michael Bertovich,* \\ Gisela Moehren, ${ }^{\dagger}$ Hilary Koprowski,* and Frank H. Michaels* \\ *Biotechnology Foundation Laboratories and 'Department of Pathology, \\ Thomas Jefferson University, Philadelphia, Pennsylvania, U.S.A.
}

\begin{abstract}
Background: The production of nitric oxide by type II inducible nitric oxide synthase (type II NOS) gene is controlled at least in part by transcriptional activation. Although the murine and human type II NOS genes share significant sequence homology, they differ in the induction stimuli required for activation.

Materials and Methods: The A549 human and murine RAW 264.7 cell lines were cultured in the presence of inducers of the type II NOS gene and exposed to specific inhibitors of phosphatidyl choline-specific phospholipase C, NF- $\kappa \mathrm{B}$, and endocytosis, as well as to reagents that deplete stores of ATP or prevent the acidification of endosomes. The effect of these reagents on the induction of the type II NOS gene transcription, translation, and NO expression was studied using electromobility shift assays, Western blotting, and the detection of NO as nitrates, as appropriate. Additionally, the ability of the native human type II NOS NF- $\kappa \mathrm{B}$ recognition sequence to bind NF- $\kappa \mathrm{B}$ was compared with a concensus sequence and with a mutated oligomer.
\end{abstract}

Results: Type II NOS production by both human and mouse cells could be prevented by the addition of the specific inhibitor of phosphatidylcholine-specific phospholipase C, D609, and of agents that interfere with the activation of NF- $\kappa$ B. Both mouse and human cells also required acidic endosome formation and the production of 1,2-diacylglycerol for type II NOS expression. Additionally, the native human type II NOS NF- $\kappa \mathrm{B}$ recognition sequence bound NF- $\kappa \mathrm{B}$ with significantly less affinity than did the recognition sequence derived from the human immunoglobulin light-chain gene promoter.

Conclusions: These experiments show that whereas mouse cells can be activated by lipopolysaccharide to produce nitric oxide, and human cells require activation by a mixture of cytokines to produce nitric oxide, the intracellular activation pathway following receptor binding of these heterologous stimuli is shared. Additionally, NF- $\kappa \mathrm{B}$ activation is necessary but not sufficient for inducible nitric oxide synthase production in human cells, in contrast to murine cells in which it serves as a complete inducer.

\section{INTRODUCTION}

The free radical nitric oxide (NO) has multiple functions. It acts as a vasoregulatory mediator (1) and a neurotransmitter (2) and plays a major role in immunosurveillance (3). Nitric oxide is synthesized from the substrate L-arginine by one of three isoforms of nitric oxide synthase (NOS). Until recently, it was believed that the enzymes

Address correspondence and reprint requests to: Frank $\mathrm{H}$. Michaels, Room 462, Jefferson Alumni Hall, Thomas Jefferson University, 1020 Locust Street, Philadelphia, PA 19107, U.S.A. Tel: 215-503-0712; Fax: 215-923-7145. could be categorized as constitutive or inducible on the basis of expression behavior. Two of the isoforms, commonly referred to as constitutive NOS (cNOS, type I NOS), were differentiated on the basis of observed activation dependence on intracellular calcium levels. The third isoform (iNOS, type II NOS) was considered distinct because control of the enzyme's activity rested at the transcriptional level. In certain cases, however, the cNOS isoforms are activated by increased transcription rates $(4,5)$, and iNOS is constitutively activated in some respiratory tissues as well as in specific cell lines (6). These are 
likely to be important, because it is becoming increasingly clear that NO production is critical for the maintenance of homeostasis as well as of host defense, and that the organism has multiple strategies to control NO production.

Type I and type II NOS are also differentiated by the amount of NO produced and the inductive stimuli that elicit NO production. The concentrations of NO resulting from type I NOS activation are usually much lower than those produced by type II NOS (7). In addition, type I NOS activation is brief, whereas type II NOS persists for many hours to days after induction. Furthermore, type I NOS is activated by intracellular calcium transients, whereas human type II NOS is induced by the inflammatory cytokines IL- $1 \beta$, TNF- $\alpha$, and IFN- $\gamma$. In mouse and rat monocytoid cells, type II NOS activity increases in response to lipopolysaccharide (LPS), and the activity is significantly enhanced by IFN- $\gamma(8,9)$. Stimulation of NO production in human monocytes has only rarely been reported $(10,11)$.

The mouse IFN- $\gamma$-responsive element was localized to a region 913 to 1029 base pairs (bp) from the transcriptional start site and shown to be functional (12). The murine iNOS gene transcriptional response element responsive to LPS stimulation has been identified as NF- $\kappa \mathrm{B}$ (13), an element also present in the human type II NOS gene promoter. These studies clearly showed that control of the murine type II NOS gene occurs predominantly at the transcriptional level, and NF- $\kappa \mathrm{B}$ is pivotal in the induction of murine type II NOS. The specific promoter response elements, however, that influence the human analogue are not as well defined.

Induction of human type II NOS requires exposure of cells to specific cytokines (7). IL-1 $\beta$ elicits low-level production of iNOS, whereas TNF- $\alpha$ or IFN- $\gamma$ alone is without stimulatory capacity. When IFN- $\gamma$ is added to TNF- $\alpha$ or IL- $1 \beta$, a significant enhancement in NO production is observed, and maximal expression of type II NOS is achieved by using all three cytokines simultaneously. Functional analysis of the first 5 kilobases of the human promoter region showed that most of the transcription control appeared to reside in an 1800-bp region upstream from the TATA box (14). The first $400 \mathrm{bp}$, which contained the NF- $\kappa$ B region critical for murine iNOS induction, was found to be without activity $(14,15)$. These studies suggested that the predominant promoter activity in the human iNOS gene lay in regions upstream from the response elements shown to be critical for control of the mouse gene.

Several observations suggest that this conclusion may not be valid. First, the same cytokines that up-regulate the expression of type II NOS in human cells have been shown to transcriptionally activate other cellular responses through increased binding of NF- $\kappa \mathrm{B}$, indicating that NF- $\kappa \mathrm{B}$ activation occurs in these cells. TNF- $\alpha$ stimulates the increased expression of class I and class II histocompatibility antigens as well as the expression of several cytokines through NF- $\kappa$ B (16). IL-1 $\beta$ binding to the type I receptor has also been shown to activate cells through NF-kB binding (17). Indeed, IL- $1 \beta$ treatment of human A549 cells that can express NO (18) resulted in the induction of NF- $\kappa B$ (19). It has also been reported that human type II NOS induction can be prevented by the action of glucocorticoids $(20,21)$, which are known to prevent the activation of NF- $\kappa B(22,23)$. Finally, functional studies have shown that the murine iNOS promoter is functional in human cells. Kleinert and co-workers used a construct consisting of a 1711-bp murine type II NOS promoter coupled to a luciferase reporter gene to show that human A549 cells supported promoter activity (24). They concluded that NF- $\kappa$ B was critical to the response because luciferase activity was significantly diminished if the cells were exposed to glucocorticoids or to the NF- $\kappa$ B inhibitor, pyrrolidine dithiocarbamate (PDTC).

These observations suggest that NF- $\kappa \mathrm{B}$ activity is also critical for the induction of human type II NOS activity. To test this hypothesis, we first showed that activation of a reporter construct containing the first $1800 \mathrm{bp}$ of the human type II NOS promoter region was prevented by PDTC. These results were confirmed with data from electromobility shift assays showing that NF- $\kappa \mathrm{B}$ levels were increased in cytokine-activated human cells. On the basis of these results, we examined several of the transduction steps previously identified, following either TNF- $\alpha$ or IL- $1 \beta$ activation of human cells, which led to increased NF- $\kappa$ B concentrations. Both TNF- $\alpha$ and IL- $1 \beta$ mediate the activation of phosphatidylcholinespecific phospholipase C (PC-PLC), which cleaves phosphatidyl choline to yield the secondmessenger species, 1,2-diacylglycerol (1,2 DAG). Concomitant with the endocytosis of the cytokine bound to its receptor, the endosome is acidified, and a resident enzyme, acidic sphingomyelinase (acidic SMase), is activated. Acidic SMase in turn cleaves sphingomyelin to yield yet an- 
other second messenger, ceramide, which activates $\mathrm{NF}-\kappa \mathrm{B}$ through undefined intermediaries $(25,26)$. Each of these steps was evaluated for its role in the induction of type II NOS activation in human and mouse cells.

\section{MATERIALS AND METHODS}

\section{Reagents}

${ }^{3} \mathrm{H}$-L-arginine $(36.8 \mathrm{Ci} / \mathrm{mM})$ was obtained from Dupont/NEN (Wilmington, DE). D609 and U73122 were obtained from Biomol Research Lab (Plymouth Meeting, PA). All other chemicals, unless noted otherwise, were purchased from Sigma Chemical Co. (St. Louis, MO).

\section{Cell Culture, Cytokine Activation, and Inhibitors}

RAW 264.7 murine macrophages and A549 human lung epithelioid cells were obtained from ATCC (Rockville, MD). RAW 264.7 cells were cultured in RPMI 1640 medium with $10 \%$ heatinactivated fetal calf serum, 50 units and $50 \mu \mathrm{g} / \mathrm{ml}$ penicillin and streptomycin, respectively, and $5 \mathrm{mM}$ L-glutamine. A549 cells were cultured in Hams F-12 medium with $10 \%$ heat-inactivated fetal calf serum, 50 units of penicillin, $50 \mu \mathrm{g} / \mathrm{ml}$ streptomycin, and $5 \mathrm{mM} \mathrm{L-glutamine.}$

RAW 264.7 cells were activated for NO production with $1 \mu \mathrm{g} / \mathrm{ml}$ LPS (E. coli 055:B5). A549 cells were induced with IL- $1 \beta(100 \mathrm{u} / \mathrm{ml})$, IFN- $\gamma$ $(500 \mathrm{u} / \mathrm{ml})$, and TNF- $\alpha(10 \mathrm{ng} / \mathrm{ml})$. Inhibitors were added to cell cultures $30 \mathrm{~min}$ before activation and included D609, U73122, neomycin sulfate, 2-nitro-4-carboxyphenyl-N,N-diphenylcarbamate (NCDC), rotenone, oligomycin, antimycin A, colchicine, monensin, and PDTC. Cell viability was quantified with trypan blue, and cells used in the reported experiments were all found to have greater than $90 \%$ viability after exposure to the reagents listed in Table 1.

\section{Assay for Phosphatidylcholine-specific Phospholipase C}

The PC-PLC activity was estimated from 1,2 DAG production assayed as previously described (27). RAW 264.7 cells were cultured in serum-free medium for $16 \mathrm{hr}$ and $1 \times 10^{7}$ cells were activated for the indicated times with $1 \mu \mathrm{g} / \mathrm{ml}$ LPS. D609 was added 30 min before activation. At the indicated times after activation, the cells were scraped from the culture substrate, and lipids
TABLE 1. Effective concentrations of phospholipase $C$ and endocytosis inhibitors, and lysomotrophic amines in suppressing type II NOS production by human and mouse cells

\begin{tabular}{lcc}
\hline & \multicolumn{2}{c}{ Cells Tested } \\
Inhibitor & A549 & RAW 264.7 \\
\hline Phospholipase C inhibitors & ED50 $^{a}$ \\
D609 & $18 \mu \mathrm{g} / \mathrm{ml}$ & $25 \mu \mathrm{g} / \mathrm{ml}$ \\
U73122 & $8 \mu \mathrm{M}$ & $6 \mu \mathrm{M}$ \\
Neomycin sulfate & $14 \mathrm{mM}$ & $13 \mathrm{mM}$ \\
NCDC & $64 \mu \mathrm{M}$ & $108 \mu \mathrm{M}$ \\
Endocytosis and & & \\
$\quad$ lysomotrophic & & \\
$\quad$ amines & & \\
Rotenone & $0.2 \mu \mathrm{M}$ & $50 \mu \mathrm{M}$ \\
Oligomycin & $0.5 \mu \mathrm{g} / \mathrm{ml}$ & $0.5 \mu \mathrm{g} / \mathrm{ml}$ \\
Antimycin & $0.1 \mu \mathrm{M}$ & $130 \mu \mathrm{M}$ \\
Monensin & $10 \mu \mathrm{M}$ & $38 \mu \mathrm{M}$ \\
Ammonium & $17 \mu \mathrm{M}$ & $50 \mu \mathrm{M}$ \\
$\quad$ chloride & $100 \mu \mathrm{M}$ & $200 \mu \mathrm{M}$ \\
Colchicine & & \\
\hline
\end{tabular}

${ }^{a}$ ED50 is the concentration determined to suppress type II NOS production by $50 \%$ of that produced in untreated cultures identically stimulated.

were extracted by resuspending the cell pellet in $4 \mathrm{ml}$ ice-cold chloroform/methanol (1:2) followed by incubation on ice for $30 \mathrm{~min}$. After the addition of $1.25 \mathrm{ml}$ water and $1.25 \mathrm{ml}$ chloroform, the extract mixture was centrifuged $(4000$ $\mathrm{rpm}$ ) for $30 \mathrm{~min}$ at $4^{\circ} \mathrm{C}$. The organic phase was collected and evaporated to dryness under nitrogen. Following solubilization in chloroform/ methanol (2:1), the lipids were spotted onto HPTLC plates (Merck, SilicaGel 60, Dorval, Quebec), and chromatographically resolved using a mobile phase of hexane/diethyl ether/acetic acid (40:10:1). The 1,2-DAG standards were run in parallel in all assays. The resulting bands were stained with Coomassie R-250, and the staining intensity of the 1,2 DAG bands was estimated by densitometry using an LKB Ultrascan (Uppsala, Sweden) laser densitometer.

\section{Quantitation of NOS Activity and NO Production}

NO was measured as the breakdown product, nitrite, using the Griess reaction. Culture supernatants $(200 \mu \mathrm{l})$ were mixed with $100 \mu \mathrm{l}$ of 
Griess reagent consisting of $0.05 \% \mathrm{~N}$-( 1-naphthyl) ethylenediamine dihydrochloride and $0.5 \%$ sulfanilamide in $2.5 \%$ phosphoric acid and allowed to react for $5 \mathrm{~min}$. A standard curve was prepared using defined concentrations of sodium nitrite solution in culture medium. Optical densities were measured at $550 \mathrm{~nm}$ with a microplate reader.

The arginine-to-citrulline assay was used to monitor routinely that the detected nitrite originated from NOS activity. Activated or control cells were detached from culture vessels with trypsin, washed twice with phosphate-buffered saline (PBS), counted, and resuspended in five volumes of lysis buffer $(50 \mathrm{mM}$ Tris, $\mathrm{pH}$ 7.5, $1 \mathrm{mM}$ dithiothreitol and protease inhibitor mixture Complete [Boehringer Mannheim, Indianapolis, IN]). Cells were lysed by three freeze-thaw cycles and lysate was cleared by centrifugation at $15,000 \times g$ for $15 \mathrm{~min}$. Reaction was initiated by addition of lysis buffer containing (final concentrations) $1 \mathrm{mM}$ NADPH, $10 \mu \mathrm{M}(6 \mathrm{R})-5,6,7,8$ tetrahydro $\mathrm{L}$ biopterin $\mathrm{HCl}, 100 \mu \mathrm{M} \mathrm{CaCl}_{2}, 50$ $\mathrm{nM}$ calmodulin, $10 \mu \mathrm{M}$ FAD, and $1 \mu \mathrm{Ci}{ }^{3} \mathrm{H}-\mathrm{L}$ arginine. The mixture was incubated for $60 \mathrm{~min}$ at $37^{\circ} \mathrm{C}$, and a $150 \mu \mathrm{l}$ aliquot was loaded onto a cation exchange column (AG 50W-Xg, Bio-Rad, Hercules, CA), then eluted with water. The eluate was collected and the radioactivity present was quantified by liquid scintillography. The general NOS inhibitor methyl L-arginine and the type II NOS inhibitor trifluoperazine were used to confirm that the NO was produced by iNOS.

\section{Western Blotting}

Cells were activated or not, as described, washed with PBS, and lysed in $2 \%$ sodium dodecyl sulfate (SDS). The protein concentration in lysates was determined with the DC Protein Assay kit (BioRad). Each sample $(50 \mu \mathrm{g})$ was loaded on a $10 \%$ SDS-PAGE gel and, following electrophoresis, transferred to a nitrocellulose membrane (Schleicher and Schuell, Keene, NH). The membrane was incubated in triethanolamine-buffered saline with 5\% nonfat dry milk (Carnation) and the 130-kDa band of mouse iNOS was detected with rabbit anti-iNOS antibodies (Santa Cruz Biotechnology, Inc., Santa Cruz, CA). Bound rabbit antibodies were visualized with the Vector $\mathrm{ABC}$ Elite kit (Burlingame CA).

\section{RNase Protection Assay}

RNase protection assays were done using a Promega RNA protection kit (Madison, WI) accord- ing to the manufacturer's instructions. Cells were activated for $5 \mathrm{hr}$ and total RNA was extracted with RNAzol (Cinna/Biotecx, Houston, TX). Fifty micrograms of total RNA was used for hybridization with a human or a mouse type II NOS-specific probe. The mouse type II NOS probe was prepared by excising a 418-base fragment (positions 54 to 471 from the sequence reported by Xie et al. [13]; Genbank accession number M87039). The fragment was cloned into pBluescript (Clonetech, Palo Alto, CA), and the negative polarity RNA was transcribed using T3 polymerase. Human reagents were similarly prepared using a 179-base fragment for human iNOS (positions 2946 to 3124 from the sequence reported by Geller et al. [21]; Genbank accession number L09210).

\section{Electrophoretic Mobility Shift Assays}

Human cells were activated for $1 \mathrm{hr}$ with the cytokine mixture described previously; murine cells were treated with LPS, also as described, and nuclei were collected using the method of Stein and coworkers (28). Nuclear extracts were prepared by three cycles of freezing and thawing in lysis buffer containing $250 \mathrm{mM}$ Tris, $\mathrm{pH} 7.8,60 \mathrm{mM} \mathrm{KCl}, 1$ $\mathrm{mM}$ dithiothreitol, $1 \mathrm{mM}$ phenylmethylsulfonyl fluoride, and $5 \mu \mathrm{g}$ of protein used in each experiment. The gel shift determinations were performed using the Gel Shift Assay System (Promega) according to the manufacturer's recommendations. The ${ }^{32}$ P-labeled, double-stranded DNA probe was end labeled with $\left[\gamma^{32} \mathrm{P}\right]$ ATP (Dupont/NEN; 6000 $\mathrm{Ci} / \mathrm{mM})$, and $5 \times 10^{4} \mathrm{cpm}$ were used per assay. The following probes were used (the binding site is underlined): An NF- $\kappa$ B consensus 5'-AGT TGA GGG GAC TTT CCC AGG C-3'; the human iNOS NF- $\kappa$ B (hNF- $\kappa$ B) 5 '-CAA GCT GGG GAC ACT C CCTTT- $3^{\prime}$, which is actually a fragment of the DNA from the human iNOS promoter (position -123 through $-102 \mathrm{bp}$ containing the NF- $\kappa \mathrm{B}$ binding site); and a mutated human iNOS NF $\kappa \mathrm{B}$ (hNF$\kappa$ Bmu) 5'-CAA GCTGAA AGC ACTCCC TTT-3', which served as a specificity control (the mutated bases are shown in bold).

\section{RESULTS}

Treatment of RAW 264.7 cells with LPS or treatment of human A549 cells with IL-1 $\beta$, IFN- $\gamma$, and TNF- $\alpha$ stimulated the production of NO, which was detected by the accumulation of nitrite in culture supernatants. RAW 264.7 cells 
produced up to $100 \mu \mathrm{M}$ of nitrite during $24 \mathrm{hr}$ of culture, whereas the A549 cells produced approximately 10 -fold less. To confirm that the observed nitrite accumulation was related to NO production, cell lysates were examined in a citrulline assay. The conversion rate of ${ }^{3} \mathrm{H}$-arginine to ${ }^{3} \mathrm{H}$ citrulline was approximately $50 \mathrm{pmol}$ of arginine/ $\mathrm{hr} / 10^{6} \mathrm{RAW}$ cells and $10 \mathrm{pmol}$ arginine $/ \mathrm{hr} / 10^{6}$ A549 cells. Type II NOS was responsible for the NO produced as shown, by the ability of the NOS inhibitor methyl-L-arginine to completely inhibit the production of NO, whereas the type I NOS inhibitor trifluoperazine was without effect.

\section{Activation of Phosphatidylcholine-specific Phospholipase C}

Activation of NF- $\kappa$ B by IL- $1 \beta$ and TNF- $\alpha$ (reviewed in 29) requires PC-PLC. As shown in Figure $1 \mathrm{~A}$ and $\mathrm{B}$, addition of the PC-PLC inhibitor D609 to the culture medium prevented nitrite production in a dose-dependent manner. Complete inhibition of nitrite production for up to $72 \mathrm{hr}$ was achieved with $50 \mu \mathrm{g} / \mathrm{ml}$ of D609 in human cells (Fig. 1C). Murine cells activated with LPS and treated with $50 \mu \mathrm{g} / \mathrm{ml}$ D609 expressed no more than $20 \%$ of the level of NO present in cultures not treated with the PC-PLC inhibitor (Fig. 1D). The data collected using the Griess reaction were confirmed with ${ }^{3} \mathrm{H}$-arginine-to- ${ }^{3} \mathrm{H}$-citrulline conversion analysis.

\section{1,2-Diacylglycerol Production}

Next we assayed the increase in 1,2-diacylglycerol production in cells following activation. Total lipids were extracted from mouse cells following stimulation and separated on thin-layer chromatography plates. The data presented in Figure 2 show that the amount of detectable DAG increased significantly. The increase was evident within $1 \mathrm{hr}$ of the addition of the activating agent, LPS. D609 significantly reduced not only the DAG levels in nonstimulated cells but also suppressed the levels seen in cells activated by LPS.

\section{Endosome Formation and Acidification: Energy Requirements}

The PC-PLC-mediated production of DAG has been shown in other systems to activate NF- $\kappa \mathrm{B}$ by a pathway that requires endosomal formation with compartmental acidification using an energy-dependent process $(29,30)$. To investigate the involvement of these steps in the induction of type II NOS, we used a series of inhibitors specific for each of the steps. Endosomal formation, prevented by the addition of colchicine, resulted in the complete abrogation of NO production with a half-maximal inhibitor concentration of $100 \mu \mathrm{M}$ (Table 1). The addition of any of three agents that deplete intracellular ATP stores (rotenone, oligomycin, and antimycin A) likewise prevented NO production, and monensin or ammonium chloride, which have been shown to prevent endosomal acidification, blocked type II NOS activation. Concomitant studies indicated that cell viability was not significantly affected at the concentrations found to effectively inhibit NO production.

\section{$\mathbf{N F}-\boldsymbol{\kappa} \mathbf{B}$}

To determine whether D609 inhibited NF- $\kappa$ B activation in human as well as mouse cells, we used gel shift assays as shown in Figure 3. Analysis of LPS-treated RAW 264.7 nuclear extracts showed two sequence-specific gel shifts (Fig. 3A). The lower band was constitutively present in both nonactivated and activated cells, whereas the upper band was activation-dependent. Treatment of cells with D609 resulted in a reduction in the intensity of the upper band. When a 100-fold molar excess of nonlabeled consensus sequence was added, the upper band was no longer detectable. This result was not observed if equivalent amounts of either Ap2 or $\mathrm{Spl}$ consensus sequence were added to the reaction mixture. Furthermore, the addition of D609 to nuclear extracts from nonactivated cells did not change the observed binding pattern. Comparable results were obtained with nuclear extracts from human A549 cells (Fig. 3B). Activation of the cells with TNF- $\alpha$, IL-1 $\beta$, and IFN- $\gamma$ resulted in the appearance of bands that could be competed with nonlabeled NF- $\kappa$ B consensus oligomer. The addition of oligomers containing the consensus sequences for Ap2 and Spl recognition did not diminish the intensity of the NF- $\kappa B$ binding. Analysis of the intensity of the signals was quantified using a Phosphorimager (Molecular Devices). Nuclear extracts of cytokine-activated human A549 cells were arbitrarily assigned a value of $100 \%$. When the exact NF- $\kappa$ B binding site sequence from the human type II NOS promoter was used, a much weaker binding was observed under the same experimental conditions-a value nearly $8 \%$ that of the concensus sequence. Nevertheless, activation of the cells 
A

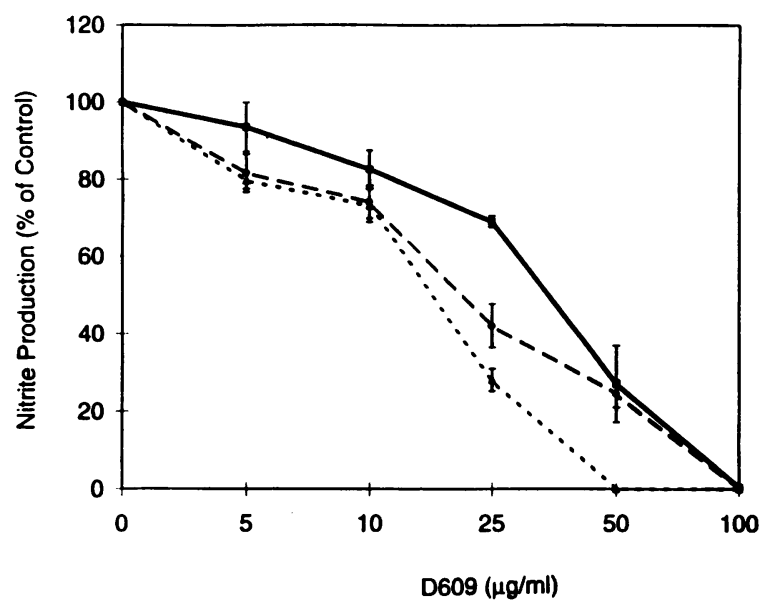

C

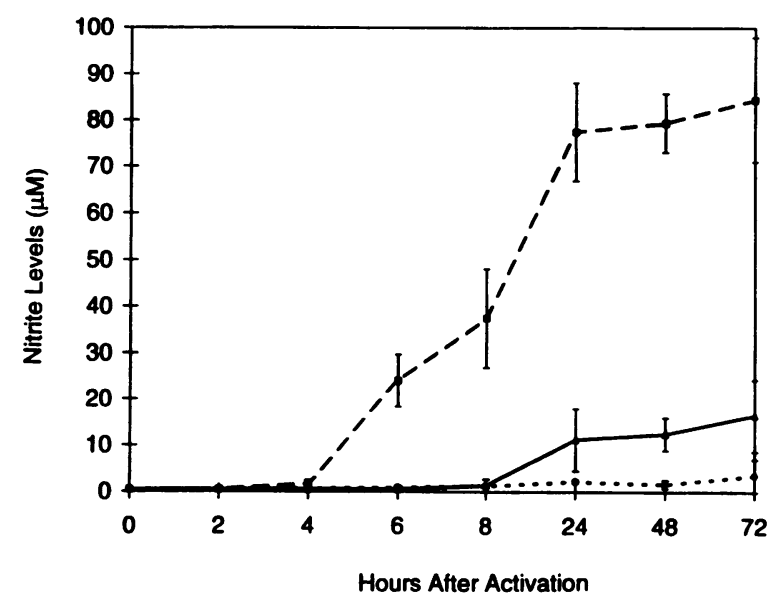

B

A549 CELLS

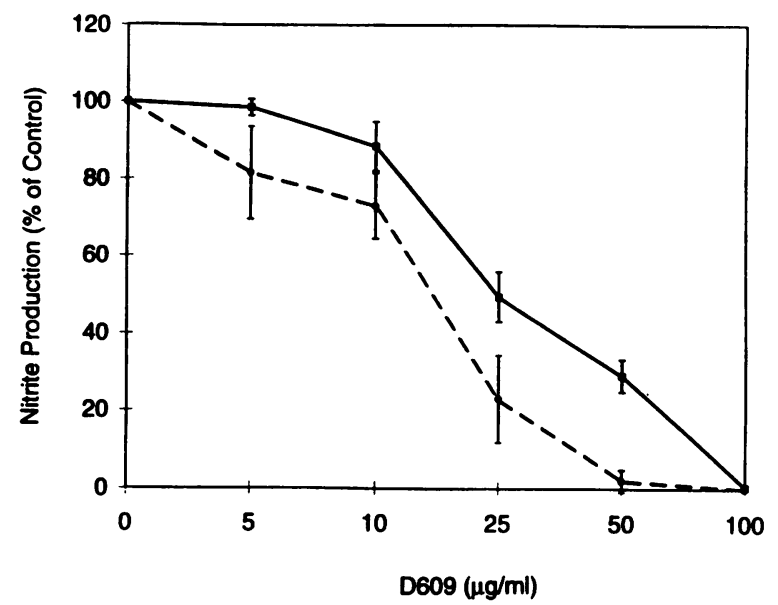

A549 CELLS

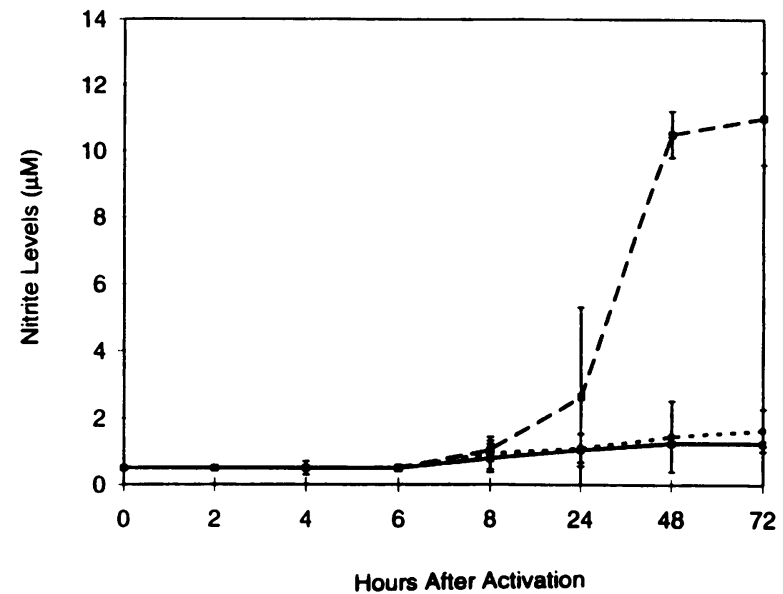

FIG. 1. Increasing concentrations of $\mathbf{D 6 0 9}$ progressively inhibit nitrite accumulation in supernatants of activated human and mouse cells and are effective for at least $72 \mathbf{~ h r}$ after stimulation

Mouse RAW 264.7 cells were incubated with increasing concentrations of D609 applied 30 min before the addition of $1 \mu \mathrm{g} / \mathrm{ml}$ LPS (A). Human cells were likewise exposed to D609, then activated with IL-1 $\beta$, IFN- $\gamma$, and TNF- $\alpha$ (B). After an 8-hr (dotted line), 24-hr (dashed line), or 48-hr (solid line) incubation period, the culture supernatants were tested for the amount of nitrite present using the Griess reaction. The data are presented as a percentage of the nitrite determined to be present in stimulated cells without D609 treatment. The ability of D609 to suppress nitrite accumulation over a period of several days was shown by adding the inhibitor $(50 \mu \mathrm{g} / \mathrm{ml})$ to stimulated mouse (C) or human (D) cells. Cells were activated as described for A and B, respectively. Unstimulated cells are represented by dotted lines, cytokine or LPS-activated cell responses, dashed lines, and activated, D609treated cell responses, solid lines. Error bars represent the SEM calculated from three independent experiments.

with cytokines resulted in increased NF- $\kappa$ B binding and D609 inhibited this up-regulation (Fig. 3C). When the reaction was done using a recognition sequence that had been mutated to disrupt the core elements critical for NF- $\kappa \mathrm{B}$ binding, no response to activation or to D609 treatment was seen (Fig. 3D). Nuclear extracts from mouse RAW 264.7 cells were also tested with NF- $\kappa$ B binding sites from human iNOS promoter. The results were similar to those presented in Figures $3 \mathrm{C}$ and $\mathrm{D}$.

\section{mRNA Determination by RNase Protection}

The transcriptional activity of D609-treated human and mouse cells was examined using an RNase protection assay. As can be seen in 


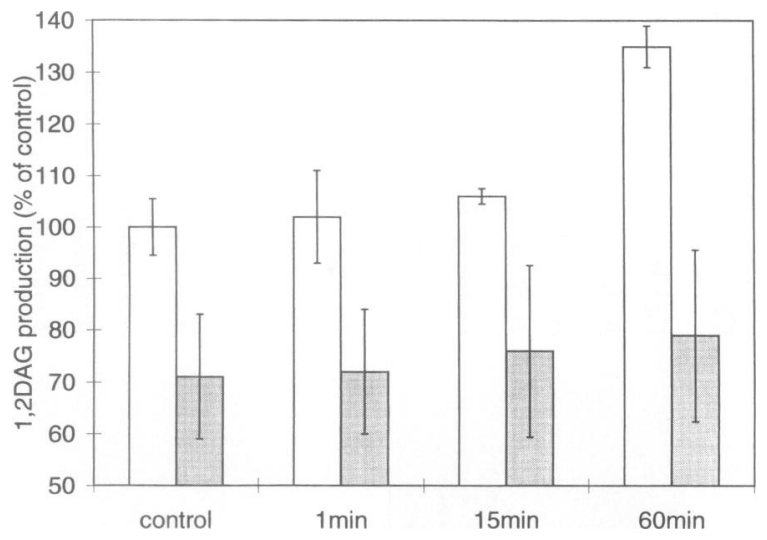

FIG. 2. LPS treatment of RAW 264.7 cells upregulates the production of 1,2 DAG and is blocked by exposure to D609

Murine cells were activated with LPS (open bars) or activated after treatment with D609 (solid bars) as described in Materials and Methods, and lipids were extracted. The extracts were chromatographed on silica gel thin-layer plates, stained with Coomassie 250 dye, and quantified with an image processor. The data presented are representative of two pooled experiments; the error bars represent the range.

Figure $4 \mathrm{~A}$ and $\mathrm{B}$, nonactivated cells contained minimal detectable iNOS-specific mRNA. Type II NOS-specific protected fragments appeared after activation but treatment of activated cells with D609 significantly decreased the intensity of the iNOS-specific bands. Neither activation nor treatment with D609 changed the mRNA levels for two housekeeping genes, human $\beta$-actin and mouse glyceraldehyde-3-phosphate dehydrogenase (GAPDH). Bands corresponding to iNOS, $\beta$-actin, or GAPDH-protected fragments were excised from gels and quantified with a scintillation counter. The amount of iNOS-specific mRNA, as cpm present in the band, was divided by the corresponding cpm of $\beta$-actin or GAPDH mRNA, as appropriate, to normalize the results for differences in gel loading. The resulting statistics are presented in Figure 4C. Treatment with D609 lowered iNOS-specific mRNA levels 3 -fold in murine cells and 13-fold in human cells.

\section{Protein Production by Western Blotting}

To confirm that D609 treatment resulted in a reduced level of type II NOS expression, we quantified type II NOS protein levels in RAW 264.7 and A549 cells cultured in the presence and absence of D609 using Western blots. The characteristic 130-kDa iNOS band was detected in extracts of activated cells but not in extracts of unstimulated cells (Fig. 5). A significant decrease in the intensity of the $130-\mathrm{kDa}$ band was seen in stimulated cells treated with D609.

\section{DISCUSSION}

The induction of human type II NOS is believed to be controlled predominantly at the transcriptional level, as has been reported for the mouse enzyme (31). A direct comparison of the nucleotide sequences of the mouse and human promoter regions $(14,32)$ shows significant homology, suggesting that similar transcriptional activation mechanisms should exist. However, the pivotal involvement of the human NF- $\kappa \mathrm{B}$ binding domain has not been clearly shown. The results of the experiments reported here clearly indicate that cytokine activation of human A549 cells results in the significant increase in NF- $\kappa \mathrm{B}$ present in the nuclei of induced cells as determined by electromobility shift assay. Our results indicate further that the nuclear binding factor is specific for both a consensus NF- $\kappa \mathrm{B}$ sequence and the exact sequence of the human iNOS NF- $\kappa \mathrm{B}$ present between positions -106 and -116 as determined from the nucleotide sequence of the region $(14,32,33)$. Interestingly, the amount of cytokine-induced human NF- $\kappa \mathrm{B}$ bound appeared to be 10 -fold less when the authentic sequence was used as a probe than when the consensus sequence was used. The two sequences differ by only two bases: one conservative substitution and one not (see legend to Fig. 5). We speculate that a diminished binding of the native human NF- $\kappa \mathrm{B}$ sequence is responsible for the weaker signal observed with the exact human sequence, as nuclear extracts from the same pool of cytokine activated cells were used for the gel shift assays. It has been consistently observed that human cells express significantly less iNOS-produced NO than do murine cells, and it is possible that a fundamental reason for this discrepancy is the weaker binding of the NF- $\kappa$ B to the human type II NOS promoter compared with the murine analogue. We have observed in previous experiments that reporter constructs containing the human type II NOS promoter region were significantly more active after transfection into murine cells than into human cells, indicating that one or more cell-specific factors strongly influenced promoter activity. Studies are in progress to evaluate this possibility. It is nevertheless clear that NF- $\kappa \mathrm{B}$ 

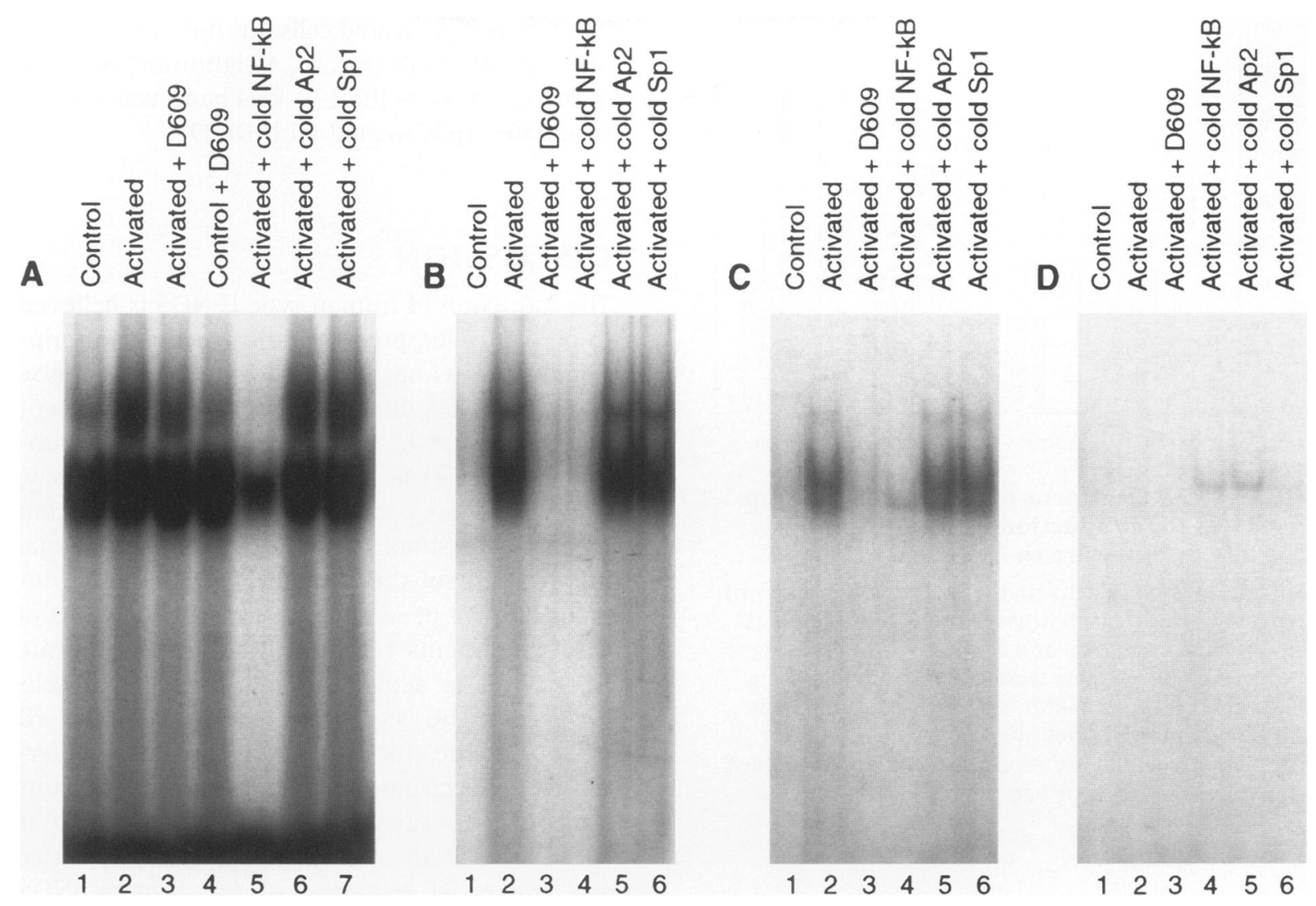

FIG. 3. Electromobility shift assay using unactivated, activated, and activated, D609-treated mouse and human cells

Nuclear extracts were prepared from unactivated, activated, or activated, D609-treated mouse (A) or human (B, C, D) cells. The extracts were incubated with radiolabeled probes containing different recognition sequences specific for either consensus NF- $\kappa$ B (A, B: 5'-AGT TGA GGG GAC TTT CCC AGG C-3'). In indicated cases, extracts were incubated with a 100-fold molar excess of unlabeled oligomers containing NF- $\kappa$ B or Apl or Sp2 binding motifs. Panel $C$ shows the results of a representative experiment in which nuclear extract from control or activated A549 cells was incubated with an oligomer with the sequence 5'-CAA GCT GGG GAC ACT CCC TTT-3', which is the exact DNA sequence of the human type II NOS promoter NF- $\kappa$ B binding site (position -123 through -102). A mutated sequence (5'-CAA GCT GAA AGC ACT CCC TTT-3') was used in D, the mutated bases are in bold type. All binding sites are underlined.

plays a pivotal role in the induction of human type II NOS.

The stimuli required for type II NOS induction in murine and human cells differ significantly, suggesting that despite promoter sequence similarities, other factors may account for the disparity in induction requirements. Murine cells are efficiently activated with LPS and IFN- $\gamma$ whereas IL- $1 \beta$, TNF- $\alpha$, and IFN- $\gamma$ are required for the activation of human cells. Despite the apparent differences in the stimuli needed by human and murine cells, we found significant similarities in the signal transduction paths involved, culminating in the expression of type II NOS.

Addition of the PC-PLC inhibitor D609 to cultures of stimulated RAW 264.7 or A549 cells resulted in essentially complete inhibition of the production of NO by human cells and an $80 \%$ reduction in murine cells. Murine cells could be completely inhibited at D609 concentrations of $100 \mu \mathrm{g} / \mathrm{ml}$ (Fig. 1), a dose not used in the experiments reported here and substantially less than the $175 \mu \mathrm{M}$ required for toxicity. D609 has been reported to be a highly specific inhibitor of PCPLC (34). It can be seen in Table 1 that the $\mathrm{ED}_{50}$ varied between mouse and human cells for several other of the inhibitors tested, which suggests that the cells are differentially susceptible to many of the agents. We also found that additional PLC inhibitors of less selectivity (NCDC, U73122, and neomycin sulfate) also variably inhibited the generation of type II NOS (Table 1). 
A
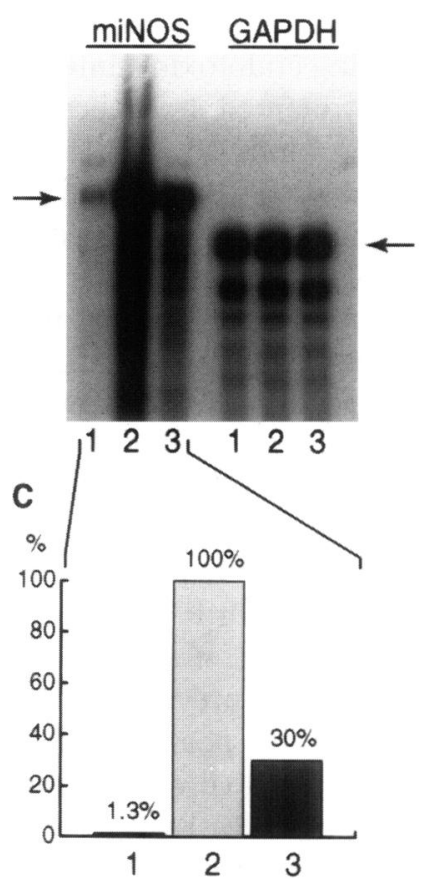

B
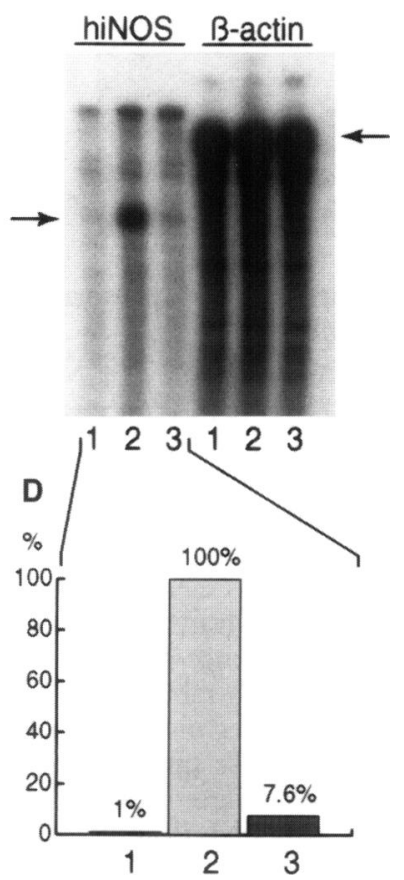

FIG. 4. D609 inhibits transcriptional activation of the type II NOS gene in human and mouse cells

(A) Mouse RAW 264.7 cells were activated with $1 \mu \mathrm{g} / \mathrm{ml}$ LPS for $5 \mathrm{hr}$, and RNA was collected. An aliquot of 50 $\mu \mathrm{g}$ of total RNA was hybridized with a mouse type II NOS probe prepared from a 418-base, radiolabeled fragment (position 54-471 from the sequence of Xie et al. [13]; Genbank accession number M87039), or a loading control consisting of a radiolabeled, 315-base fragment specific for mouse GAPDH. Following RNase digestion, the mixture was resolved on a polyacrylamide gel and subjected to autoradiography; the results are presented in Fig. 3A. Lanes 1 represent the protected fragments derived from unactivated cells, lanes 2 were derived from LPS-activated cells, and lanes 3 were derived from activated, D609-treated cells. (B) Human A549 cells were activated; total RNA was isolated and hybridized to a human type II NOS radiolabeled probe derived from a 179-base sequence of human type II NOS (position 2946-3124 reported by DA Geller et al. [21]; Genbank accession number L09210). All other experimental protocols were as described for the mouse RNase protection assay. The data are presented in B. (C) The type II NOS-specific bands (indicated by arrows) were excised from the gel, and radioactivity was quantified with a gamma counter. The data were normalized to percent of type II NOS radioactivity divided by the radioactivity present in the GAPDH loading control lane. Figure 3C presents the results of the quantitation of protected RNA isolated from control and treated murine cells. (D) Human type II NOS-protected fragments were quantified as described for murine sequences in Fig. 3C. The loading control was a 249-radiolabeled base sequence specific for human $\beta$-actin. Data are presented as described for Fig. 3C.

That PC-PLC might be pivotal in the control of human type II NOS is not surprising because it has been shown that both IL- $1 \beta$ and TNF- $\alpha$ mediate cellular activation through this pathway. IL- $1 \beta$ has been shown to enable numerous biological activities, and central to the activation process is the phosphorylation of cellular proteins through phosphokinase A or phosphokinase $C$ (35). Because the classical calcium-inositol triphosphate path is not activated by IL-1 $\beta$ (36), it has been suggested that a pathway involving PC-PLC might be employed. The involvement of PC-PLC in TNF- $\alpha$ activation transduction has been much better documented. Occupancy of the p55 receptor by TNF- $\alpha$ results in the activation of PC-PLC located in the plasma membrane. This enzyme hydrolyzes PC to yield phosphocholine and 1,2 DAG (37). The latter hydrolysis product, 1,2 DAG, activates another membrane-associated enzyme, sphingomyelinase, which hydrolytically degrades sphingomyelin to yield ceramide. More recent studies have shown that sphingomyelinase actually exists as two isomers, each of which is activated by different domains of the TNF-55kd receptor (38). The enzymes can also be differentiated on the basis of their intracellular locations and $\mathrm{pH}$ optima. A neutral sphingomyelinase is located exclusively in the plasma membrane and generates ceramide, which in turn activates a proline-directed 


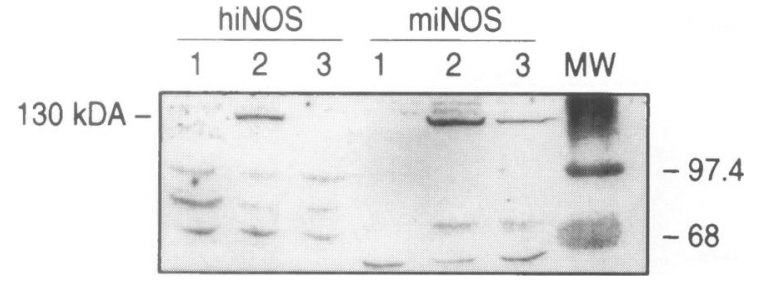

FIG. 5. D609 inhibits expression of human and mouse type II NOS protein

D609 $(50 \mu \mathrm{g} / \mathrm{ml})$ was added to cell RAW 264.7 or human A549 cell cultures 30 min before they were activated as described for Fig. 1. Following incubation for $24 \mathrm{hr}$, cells were washed with PBS and lysed in $2 \%$ SDS; the protein concentration was determined with a DC Protein Assay kit (Bio-Rad). An aliquot of $50 \mu \mathrm{g}$ of each sample was electrophoresed through a $10 \%$ SDS-PAGE gel and transferred to a nitrocellulose membrane. The presence of a $130-\mathrm{kDa}$ type II NOS band was detected with rabbit anti-type II NOS antibodies (Santa Cruz Biotechnology, Inc.). For both human (hiNOS) and mouse (miNOS) cell lysates, unactivated (lane 1) cells were compared with activated (lane 2), and activated, D609-treated cells (lane 3 ).

serine/threonine protein kinase and phospholipase A2 (38). A second form of sphingomyelinase, also activated by 1,2 DAG, is located only in endosomes and requires an acid environment for catalysis. This acidic sphingomyelinase triggers the activation of NF- $\kappa$ B through a series of intermediary steps (38). The data provided in this report indicate that the latter pathway is involved in the activation of type II NOS in both human and mouse cells; a role for the neutral sphingomyelinase is unlikely because D609 has no effect on this enzyme (38).

We further used a series of inhibitors to investigate the events distal to the generation of 1-2 DAG. When rotenone, oligomycin, or antimycin A was added to either stimulated human A549 cell cultures or mouse RAW 264.7 cultures, the production of NO was significantly inhibited. These agents have been shown to deplete ATP stores in cells, resulting in the failure of endosome acidification (39). This result was confirmed by the finding that the addition of monensin or ammonium chloride, lysomotrophic agents that also prevent endosome acidification, likewise prevented the generation of NO. The concentrations found effective were also found not to influence cell viability.

An unexpected finding reported here is that D609 efficiently inhibited NO generation by LPSactivated RAW 264.7 cells. Although the induc- tion of NF- $\kappa \mathrm{B}$ in LPS-treated cells has been shown (25), the transduction pathway used following endotoxin stimulation has been only partially defined. It has been shown that LPS specifically binds to CDI4 after interaction with a circulating LPS-binding protein, and subsequent studies have implicated protein tyrosine phosphorylation in cellular activation (26); a more detailed resolution has not been provided. Additionally, the ligand for LPS, CD 14, is a member of a class of cellular receptors that anchor within the membrane but do not penetrate the cytoplasm. Some glucosylphosphatidylinositol-anchored proteins use transduction mechanisms that require co-receptors; others remain undefined (40). It is thus surprising that blockade of the PC-PLC transduction pathway at several points can prevent the LPS-mediated induction of NO. It is possible that the postulated unidentified CDI4 co-receptor (41) may be membraneassociated PC-PLC.

It has been suggested that the transduction steps that link acidic sphingomyelinase-mediated production of ceramide with the dissociation of I $\kappa \mathrm{B}-\mathrm{a}$ to yield active NF- $\kappa \mathrm{B}$ involve either a protein kinase $(42)$ or a protein phosphatase (43). The experiments reported here did not address this possibly complex series of events (29), and experiments designed to compare intermediary events are in progress.

The data presented here indicate that NF- $\kappa \mathrm{B}$ activation of type II NOS transcription is central to the expression of the gene in both human and mouse cells, although the stimuli (LPS for mouse cells and IL- $1 \beta$, TNF- $\alpha$, and IFN- $\gamma$ for human cells) that initiate the cascade with PC-PLC activation are significantly different. Why human cells require activation by three cytokines, especially when two share a common transduction mechanism, remains to be explained. Undoubtedly, other transduction paths are active and will be the subject of future research.

\section{ACKNOWLEDGMENTS}

This work was supported by the Commonwealth of Pennsylvania.

\section{REFERENCES}

1. Moncada S, Higgs A. (1993) The L-argininenitric oxide pathway. New Engl. J. Med. 329: 2002-2012. 
2. Garthwaite J, Charles SL, Chess-Williams R. (1988) Endothelium-derived relaxing factor release on activation of NMDA receptors suggests a role as intercellular messenger in the brain. Nature 336: 385-388.

3. Nathan CF, Hibbs JB, Jr. (1991) Role of nitric oxide synthesis in macrophage antimicrobial activity. Curr. Opin. Immunol. 3: 65-70.

4. Xue C, Rengasamy A, Le Cras TD, Koberna PA, Dailey GC, Johns RA. (1994) Distribution of NOS in normoxic vs. hypoxic rat lung: Upregulation of NOS by chronic hypoxia. Am. J. Physiol. 267: L667-L678.

5. Chen S, Aston-Jones G. (1994) Cerebellar injury induces NADPH diaphorase in Purkinje and inferior olivary neurons in the rat. Exp. Neurol. 126: 270-276.

6. Mannick JB, Asano K, Izumi K, Kieff E, Stamler JS. (1994) Nitric oxide produced by human B lymphocytes inhibits apoptosis and Epstein-Barr virus reactivation. Cell 79: 1137-1146.

7. Nussler AK, Billiar TR. (1993) Inflammation, immunoregulation, and inducible nitric oxide synthase J. Leuk. Biol. 54: 171-178.

8. Stuehr DJ, Marletta MA. (1985) Mammalian nitrate biosynthesis: Mouse macrophages produce nitrite and nitrate in response to Escherichia coli lipopolysaccharide. Proc. Natl. Acad. Sci. U.S.A. 82: 7738-7742.

9. Lorsbach RB, Murphy WJ, Lowenstein CJ, Snyder SH, Russell SW. (1993) Expression of the nitric oxide synthase gene in mouse macrophages activated for tumor cell killing. Molecular basis for the synergy between interferon-gamma and lipopolysaccharide. J. Biol. Chem. 268: 1908-1913.

10. De Maria R, Graza Cifone M, Trotta R, Rippo MR, Festuccia C, Santoni A, Testi R. (1994) Triggering of human monocyte activation through CD69, a member of the natural killer cell gene complex family of signal transducing receptors. J. Exp. Med. 180: 1999-2004.

11. Bukrinsky MI, Nottet HSLM, Schmidtmayerova $\mathrm{H}$, Dubrovsky L, Flanagan CR, Mullins ME, Lipton SA, Gendleman HE. (1995) Regulation of nitric oxide synthase activity in human immunodeficiency virus type l(HIV1)-infected monocytes: Implications for HIVassociated neurological disease. J. Exp. Med. 181: $735-745$.

12. Martin E, Nathan C, Xie Q-w. (1994) Role of interferon regulatory factor 1 in induction of nitric oxide synthase. J. Exp. Med. 180: 977984.

13. Xie Q-w, Kashiwabara Y, Nathan C. (1994) Role of transcription factor NF-kB/Rel in induction of nitric oxide synthase. J. Biol. Chem. 269: 4705-4709.

14. Spitsin SV, Koprowski H, Michaels FH. (1996) Characterization and functional analysis of the human inducible nitric oxide synthase gene promoter. Mol. Med. 2: 226-235.

15. de Vera ME, Shapiro RA, Nussler AK, Mudgett JS, Simmons RL, Morris SM, Jr, Billiar TR, Geller DA. (1996) Transcriptional regulation of human inducible nitric oxide synthase (NOS2) gene by cytokines: initial analysis of the human NOS2 promoter. Proc. Natl. Acad. Sci. U.S.A. 93: 1054-1059.

16. Kronke $M$, Schultze $S$, Scheurich $P$, Pfizenmaier K. (1992) TNF signal transduction and TNF responsive genes. In: Aggarwal, BB, Vilcek J (eds). Tumor Necrosis Factor: Structure, Function and Mechanism of Action. Marcel Dekker, New York, pp. 189-216.

17. Leung K, Betts JC, Xu L, Nabel GJ. (1994) The cytoplasmic domain of the interleukin-1 receptor is required for nuclear factor-kappa B signal transduction. J. Biol. Chem. 269: 1579-1582.

18. Asano K, Chee CB, Gaston B, Lilly CM, Gerard C, Drazen JM, Stamler JS. (1994) Constitutive and inducible nitric oxide gene expression, regulation, and activity in human lung epithelial cells. Proc. Natl. Acad. Sci. U.S.A. 91: 10089-10093.

19. Ray KP, Kennard N. (1993) Interleukin-1 induces a nuclear form of transcription factor NF kappa B in human lung epithelial cells. Agents Actions Suppl. 38: C61-C63.

20. O'Connor KJ, Moncada S. (1991) Glucocorticoids inhibit the induction of nitric oxide synthase and the related cell damage in adenocarcinoma cells. Biochim. Biophys. Acta 1097: 227-231.

21. Geller DA, Nussler AK, Di Silvio M, Lowenstein CJ, Shapiro RA, Wang SC, Simmons RL, Billiar TR. (1993) Cytokines, endotoxin, and glucocorticoids regulate the expression of inducible nitric oxide synthase in hepatocytes. Proc. Natl. Acad. Sci. U.S.A. 90: 522526.

22. Scheinman RI, Cogswell PC, Lofquist AK, Baldwin AS, Jr. (1995) Role of transcriptional activation of IkBa in mediation of immunosuppression by glucocorticoids. Science 270: 283-286. 
23. Auphan N, DiDonato JA, Rosette C, Helmberg A, Karin M. (1995) Immunosuppression by glucocorticoids: Inhibition of NFkB activity through induction of $\mathrm{I} \kappa \mathrm{B}$ synthesis. Science 270: 286-290.

24. Kleinert H, Euchenhofer C, Ihrig-Biedert I, Forstermann U. (1996) Glucocorticoids inhibit the induction of nitric oxide synthase II by down-regulating cytokine-induced activity of transcription factor nuclear factorkappa B. Mol. Pharmacol. 49: 15-21.

25. Muller JM, Ziegler-Heitbrock JHW, Baeuerle PA. (1993) Nuclear factor $\kappa B$, a mediator of lipopolysaccharide effects. Immunobiology 187: 233-256.

26. Weinstein SL, Gold MR, DeFranco AL. (1991) Bacterial lipopolysaccharide stimulates protein tyrosine phosphorylation in macrophages. Proc. Natl. Acad. Sci. U.S.A. 88: 4148-4152.

27. Moehren G, Gustavsson L, Hoek JB. (1994) Activation and desensitization of phospholipase $\mathrm{D}$ in intact rat hepatocytes. J. Biol. Chem. 269: 838-848.

28. Stein B, Rahmsdorf HJ, Steffen A, Litfin M, Herrlich P. (1989) UV-induced DNA damage is an intermediate step in UV-induced expression of human immunodeficiency virus type 1, collagenase, c-fos, and metallothionein. Mol. Cell Biol. 9: 5169-5181.

29. Baeuerle PA, Henkel T. (1994) Function and activation of $\mathrm{NF} \kappa \mathrm{B}$ in the immune system. Annu. Rev. Immunol. 12: 141-179.

30. Schtuze S, Potthoff K, Machliedt T, Berkovic D, Weigmann K, Kronke M. (1992) TNF activates NF-kappa B by phosphatidylcholinespecific phospholipase C-induced "acidic" sphingomyelin breakdown. Cell 71: 765-776.

31. Xie Q-W, Whisnant R, Nathan C. (1993) Promoter of the mouse gene promoting calcium-independent nitric oxide synthase confers inducibility by interferon gamma and lipopolysaccharide. J. Exp. Med. 177: 17791784.

32. Nunokawa $\mathrm{Y}$, Ishida $\mathrm{N}$, Tanaka S. (1994) Promoter analysis of human inducible nitric oxide synthase gene associated with cardiovascular homeostasis. Biochem. Biophys. Res. Commun. 200: 802-807.

33. Chartrain NA, Geller DA, Koty PP, Sitrin NF, Nussler AK, Hoffman EP, Billiar TR, Hutchinson NI, Mudgett JS. (1994) Molecular cloning, structure, and chromosomal localization of the human inducible nitric oxide synthase gene. J. Biol. Chem. 269: 6765-6772.

34. Muller-Decker K. (1989) Interruption of TPA-induced signals by an antiviral and antitumoral xanthate compound: Inhibition of phospholipase C-type reaction. Biochem. Biophys. Res. Commun. 162: 198-205.

35. Kuno K, Matsushima K. (1994) The IL-1 receptor signaling pathway. J. Leuk. Biol. 56: 542-547.

36. Kracht $M$, Heiner A, Resch $K$, Szamel $M$. (1993) Interleukin-1 induced signalling in $T$ cells. J. Biol. Chem. 268: 21066-21072.

37. Kolesnick R, Golde DW. (1994) The sphingomyelin pathway in tumor necrosis factor and interleukin-1 signaling. Cell 77: 325-328.

38. Weigmann K, Schutze S, Machliedt T, Witte D, Kronke M. (1994) Functional dichotomy of neutral and acidic sphingomyelinases in tumor necrosis factor signaling. Cell 78: 1005-1015.

39. Mellman I, Fuchs R, Helenius A. (1986) Acidification of the endocytic and exocytic pathways. 55: 663-700.

40. Robinson PJ. (1991) Phosphatidylinositol membrane anchors and $\mathrm{T}$ cell activation. Immunol. Today 12: 35-41.

41. Ulevitch RJ, Tobias PS. (1995) Receptor-dependent mechanisms of cell stimulation by bacterial endotoxin. Annu. Rev. Immunol. 13: 437-457.

42. Mathias S, Younes A, Kan CC, Orlow I, Joseph C, Kolesnick RN. (1993) Activation of the sphingomyelin signaling pathway in intact EL-4 cells and in a cell-free system by IL-1b. Science 259: 519-522.

43. Dobrowsky RT, Hannun YA. (1992) Ceramide stimulates a cytosolic protein phosphatase. J. Biol. Chem. 267: 5048-5051. 